\title{
RESEÑA. CAMBIO Y CORONAVIRUS. REPRESTANCIONES SOCIALES. BURLA, SILENCIO Y MIEDO
}

\section{REVIEW. CAMBIO Y CORONAVIRUS. REPRESENTACIONES SOCIALES. BURLLA, SILENCIO Y MIEDO \\ RESENHA. CAMBIO Y CORONAVIRUS. REPRESENTACIONES SOCIALES. BURLA, SILENCIO Y MIEDO}

\author{
César Tolgyesi Fernández \\ Universidad de Cádiz, España \\ https://orcid.org/0000-0002-8404-7556 \\ cesar.tolgfer@alum.uca.es
}

Recibido: 01/12/2020 Revisado: 03/12/2020 Aceptado: 06/12/2020 Publicado: 04/03/2021

Autor: Carmen Vázquez Domínguez, Beatriz PérezGonzález, y Diana Salzano (Coords)

Editorial: Aula Magna. MacGraw-Hil Interamericana de España S.L.

Año: 2020

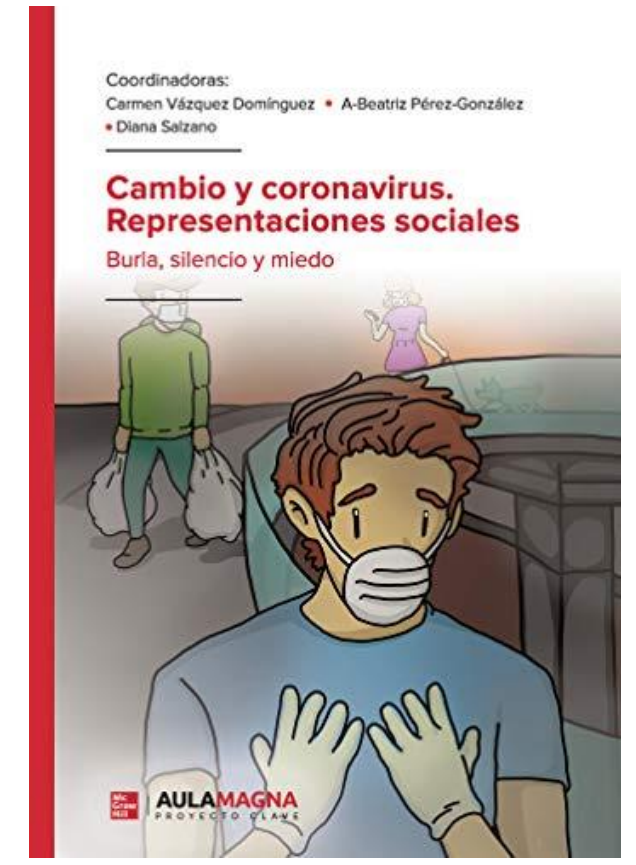

Cómo citar esta reseña: Tolgyesi, C. (2021). Reseña. Cambio y coronavirus. Representaciones sociales. Burla, silencio y miedo. Hachetetepé. Revista científica en Educación y Comunicación, (22), 1-3. https://doi.org/10.25267/Hachetetepe.2021.i22.1301

En el transcurso del confinamiento, mientras la memoria de mi móvil se convertía en memes y políticos anunciaban decisiones respaldadas por expertos anónimos, yo solía preguntarme: ¿Dónde están los sociólogos mientras la sociedad líquida se evapora y la anomía se convierte en normalidad?

Mi respuesta vino en forma de libro, escrito por 17 autores, españoles e italianos, coordinados por Vázquez Domínguez, Pérez-González y Salzano. 
Quizás muchas personas no oirán sus voces en medio del ensordecedor ruido informativo de los medios de comunicación. Pero no importa. No es un libro para entretener a nadie (para eso ya tenemos los grupos de Whatsapp y Netflix). La ilustración de la portada, titulada Caos no Infantil, de Javier Montero Pérez, nos adelanta la seriedad del tema: es un libro de retratos de nuestra era.

Cada uno de los autores es un fotógrafo, retratando el momento en que la sociedad se torna consciente de su vulnerabilidad frente a la pandemia y el miedo toma el control de la comprensión humana.

Sí, hemos perdido el control, y parece que estamos dispuestos a todo para recuperarlo.

En este sentido, Pérez-González y Vázquez Domínguez nos advierten en el primer capítulo: "No solo las normas han dado lugar a una burocratización del proceso educativo, sino también a ingeniar sistemas de control docente desde las organizaciones educativas tan solo por desconfianza". Aun sabiendo que "(...) cualquier exceso de burocratización y control interno asfixia a los miembros del sistema” (p.34).

Reflexionando acerca del compromiso entre el bien colectivo y la libertad individual, Napoli nos explica que "el virus ataca el deseo supremo de sobrevivir que debe protegerse a expensas de todo" (p. 157), incluidas las limitaciones de nuestros derechos individuales.

También Salzano ha resaltado la importancia de "trazar todavía (y siempre) el perímetro de una libertad democrática (...) que no siga la curva de los contagios y que no ceda su íntimo significado en favor de una protección difundida.” (p.52)

Sin embargo, nos hemos confinado con una infinidad de tecnologías en nuestras celdas de corresponsabilidad y miedo, intentando amenizar la situación con chistes y memes, tema que tratan agudamente Benvenga y Zaterini. Cualquier acontecimiento peligroso y global como una pandemia, genera entre la población un miedo incontrolable que hay que combatir tanto individual como colectivamente. Checa y Olmos plantea en su capítulo dos formas: las noticias falseadas y el humor.

Y así fue como el término confinamiento, según Fernández Villanueva, se convirtió en "la marca lingüística social de nuestro momento subjetivo" (p.110), extrapolando la esfera militar para ser incorporado al diccionario sanitario.

Durante el caos comunicativo de la pandemia, descrito por Lando, "la distonía y la discordancia fueron las principales características de los mensajes con los que, a lo largo de los días, se informó tanto de los 'datos de realidad' como de la acción y los pasos que deberían seguirse.” (p. 97)

Para Scognamiglio, "cuanto mayor sea la falta de conocimiento directo de la realidad fenoménica que se presenta, mayor será la posibilidad que tienen las emisoras y los medios de comunicación de definir el marco interpretativo en el que el público actuará, tanto como consumidor como productor de información." (p. 216)

Gracias a los medios de comunicación, la pandemia ha dado lugar a la infodemia, término creado en 2003, en virtud del SARS, que "se refiere a hechos (mezclados con miedo, especulación y voces), amplificados y transmitidos rápidamente en todo el mundo por modernas tecnologías de información, que afectan a las economías nacionales e internacionales, la política, e incluso, a la seguridad, de manera que se pueden manifestar absolutamente desproporcionadas para la realidad." (p. 212) Y es posible que las conclusiones del SARS también fueran aplicables a la COVID-19: "si se hubiera hecho más por la gestión eficaz y honesta, no sólo la enfermedad, sino también el flujo de 
información de la misma, el pánico mundial podría no haberse producido o habría sido mucho más contenido". (p.217)

Gavrila y Cilento sugieren que la desconfianza recíproca generada por la enfermedad es una amenaza al tejido social, razón por la cual la obra evoca a una "reflexión pública más completa de un equipo interdisciplinario de psicólogos, sociólogos y economistas, que puedan acompañar a las personas en la comprensión de la crisis y, sobre todo, en el largo camino hacia la salida.” (p. 145)

Quizás, las conjeturas filosóficas mostradas por Gil Villa estén en lo correcto: "si en las escuelas nos hubieran enseñado a cultivar nuestra vida interior (...), a descubrir el placer de la creación artística (...), a cómo mirar a la muerte (...), y valorar a nuestros mayores" (p. 173) todo habría sido distinto.

Ahora nuestras relaciones sociales ocurren en la red, flotando en alguna "nube" virtual, como explica Romeo, donde muchos gastamos las horas mirando el escaparate de la soledad humana, para no sentirnos tan solos.

La vida no será la misma después de esta crisis, y muchos autores han apuntado que esta es nuestra oportunidad para reflexionar acerca del fracaso del modelo anterior. En este sentido, Borrelli apuesta por un nuevo modelo de investigación científica para encontrar soluciones efectivas a nuestros problemas.

¿Podrá la ciencia, y solo ella, salvarnos? En el último capítulo del libro, Costa y Morcellini con hermosas palabras, escriben sobre poder de la ciencia y el de la creencia en el desafío de la vida.

\section{REFERENCIAS BIBLIOGRÁFICAS}

Vázquez Domínguez C., Pérez-González, A-B. y Salzano, D. (Coords.) (2020). Cambio y coronavirus. Representaciones sociales. Burla silencio y miedo. McGraw-Hill. 